\title{
Review Article: \\ "Adaptive governance and resilience: the role of multi-stakeholder platforms in disaster risk reduction"
}

\author{
R. Djalante \\ Department of Environment and Geography, Macquarie University, Sydney, Australia \\ Correspondence to: R. Djalante (riyanti.djalante@mq.edu.au) \\ Received: 2 November 2011 - Revised: 20 May 2012 - Accepted: 16 August 2012 - Published: 14 September 2012
}

\begin{abstract}
Disaster impacts are more frequent, deadly and costly. The social and environmental consequences are increasingly complex and intertwined. Systematic as well as innovated strategies are needed to manage the impacts. Disaster Risk Reduction (DRR) is a systematic approach to manage disaster risks while adaptive governance (AG) is suggested as an alternative approach for governing complex problems such as disasters. The author proposes that the AG can be practicalised through a mechanism of multistakeholder platforms (MSPs), interpreted as multiplicity of organisations at different scales of governance working towards more coordinated and integrated actions in DRR. Ten MSPs are selected at the global, regional, national and local level, focussing on the Indonesian MSPs. The literature reviews and in-depth interviews with key respondents in Indonesia show that the international and regional MSPs tend to have more human, technical and financial capacity than national and local MSPs. The author finds that most MSP roles focus on the coordination amongst multitudes of organisations. Only those MSPs that are able to generate new funding have the capacity to implement direct risk reduction activities. The development of the MSP is highly influenced by the UNISDR system operating at different levels. Particularly in Indonesia, MSP are also influenced by the operations of various UN and international organisations. Finally, the paper suggests the need for more provision of technical supports to local MSPs, more linkages with established networks in DRR and broader stakeholders involvement within the MSPs.
\end{abstract}

\section{Introduction}

There is a global concern that natural disasters are becoming more frequent, deadly and costly (UNISDR, 2011a; EMDAT, 2010; Germanwatch, 2010; UNU-EHS, 2011; IFRC, 2010; Maplecroft, 2010). Disasters are also more complex and the impacts to the society and the environment are increasingly more intertwined. Disaster Risk Reduction (DRR) has been proposed as a systematic mechanism to reduce disaster risks by analysing and managing the causal factors of disasters including the reduction of vulnerability and improved preparedness for adverse events (UNISDR, 2011a). The Hyogo Framework for Action (HFA) 20052015: Building the Resilience of Nations and Communities is the internationally agreed framework to guide the comprehensive and systematic application of DRR activities (UNISDR, 2007b). Resilience to disasters is defined as the ability of a community or society that is exposed to hazards to resist, absorb, accommodate and recover from hazards quickly and efficiently (UNISDR, 2009a), and building resilience has increasingly been adopted as the ultimate goal for DRR (UNISDR, 2011d).

Many researchers are calling for more innovative and integrated governance approaches in dealing with complex problems posed by disasters (Renn, 2008; Fung, 2006; Ikeda et al., 2008; IGRP, 2010). In this paper, governance is defined as the intentional shaping of the flow of events to realise desired public needs (Parker and Braithwaite, 2003), differentiated from government, which is taken to mean political authority or state control (Freeman, 1997). An adaptive governance (AG) approach is put forward as an alternative method of managing complex social-environmental problems including disasters (e.g. Brunner et al., 2005; Folke et al., 2005; 
Dietz et al., 2003; Djalante et al., 2011). AG calls for new governance systems that are "less rigid, less uniform, less prescriptive and less hierarchical, and promise a more innovative but effective way of dealing with complex environmental problems" (Holley, 2010). One proposed innovation for more flexible and participatory methods of governance is through the multi-stakeholder platform (MSP), defined by Steins and Edwards (1999, p. 244) as:

"Decision making bodies (voluntary or statutory) comprising different stakeholders who perceive the same resource management problem, realise their interdependence for solving it, and come together to agree on action strategies for solving the problem."

The United Nations International Strategy for Disaster Reduction (UNISDR) explains the MSP as a mechanism that serves as an advocate for DRR towards coordination, analysis and advice on areas of priority needing concerted action (UNISDR, 2007a). The author similarly defines the MSP as a multiplicity of organisations at different scales of governance working towards more coordinated and integrated actions in DRR. Recent global reviews on the progress in DRR, such as the Mid-Term Review of the HFA (UNISDR, 2011e) and the Global Assessment Report (UNISDR, 2011a), stated that MSPs play important roles in integrating DRR into sustainable development policies and supporting less developed countries in implementing the HFA (UNISDR, 2011a). However, despite increasing recognition of the role of MSPs, there have been no studies that comprehensively examine the roles, interlinkages and collaborations between MSPs to build disaster resilience. This paper establishes that MSPs can be an alternative mechanism to implement $\mathrm{AG}$, which can in turn help to build resilience to disasters.

Taking the global, regional (Asia) and Indonesia MSPs as the case studies, the paper asks the following two questions:

1. How are MSPs formed, organised and coordinated?

2. How are the MSPs linked, when do they collaborate, and to what extent do the global and regional MSPs support the Indonesian MSPs in building disaster resilience?

The first question is addressed by applying the proposition of Djalante et al. (2011) on the relationships between the key characteristics of AG (polycentric and multi-layer institutions, participation and collaboration, self-organisation and networks, and learning and innovation) and their implications in building disaster resilience. This framework is utilised since it is the only framework that specifically and systematically reviews the relationships between AG and disaster resilience. The following analytical questions are in reference to

1. Polycentric and multi-layer institutions: How do the MSPs complement existing forms of DRR governance?
2. Participation and collaboration: To what extent are these MSPs inclusive of diverse members of society?

3. Self-organisation and networks: Are these MSPs actively mapped into the broader networks of inter-MSP collaboration?

4. Learning and innovation: How do experiences from past disasters affect the development and operation of MSPs?

The second set of questions is addressed by applying the Biermann et al. (2007) framework on partnership implementation deficit. The framework is the one that specifically examines the effect of collaboration and partnership in development sector. The original analytical factors are slightly modified in this paper, forming the following questions:

1. Do the MSPs have the required capacity (human/organisations and technical resources) to implement their programmes and support other MSPs?

2. Do the MSPs generate new sources of funding and to what extent do these funds evolve to other MSPs?

3. Do the MSPs focus on direct effects in reducing disaster risks or target more vulnerable groups?

Indonesia is selected as the case country because of its vulnerability to multiple natural hazards, mainly geophysical and hydro-meteorological (EM-DAT, 2011; Maplecroft, 2010; The World Bank, 2005). There have been approximately 400 natural disasters that have killed close to 241000 people, affected almost 28 million people and cost approximately US\$24 billion (EM-DAT, 2011). Another reason for selecting Indonesia amongst other countries in the region is that there has been strong progress and proliferation of MSPs at the national and local level, and also thematically for HFA, which makes the country stand out amongst others. To provide a comprehensive overview by which the MSPs operate, the analyses include those at the southeast Asian and Asian regions within which Indonesia is located. Selecting the region is also important considering that it is most vulnerable to natural hazards (UNU-EHS, 2011; EM-DAT, 2010; Germanwatch, 2011) and climate change (Maplecroft, 2011; IPCC, 2007).

This paper is part of the larger study that examines the interlinkages between the concepts of AG, resilience and DRR, and apply those concepts to examine activities and institutions involved in building resilience to disasters and climate change in Indonesia. Several related publications include important processes and components of disaster resilience (Djalante and Thomalla, 2011), AG and DRR (Djalante et al., 2011), progress in building resilience in Indonesia through the implementation of the HFA (Djalante et al., 2012), and integration of DRR and climate change adaptation (CCA) 
in Indonesia (Djalante, 2013; Djalante and Thomalla, 2012). This paper contributes to the larger study through utilising the key findings from the paper on the relationships between AG and disaster resilience (Djalante et al., 2011) to analyse the roles of MSPs in DRR, to build resilience in Indonesia.

\section{Methodology}

This paper utilises a combination of methods for data collection. Discussions of MSPs were sourced from the academic literature as well as from reports published by organisations with experience in implementing or researching MSPs in different sectors. The author conducted Internet searches using the keywords "multi-stakeholder platforms or forums for DRR" performed both in English and Bahasa Indonesia. In-depth key informant interviews were conducted with 8 personnel of key organisations related to the Indonesian MSPs (Table 1). The interviews took place between October 2010 and January 2011, focussing on collecting information on

1. activities related to DRR and CCA,

2. progress in building disaster resilience and

3. the roles of MSPs in building disaster resilience in Indonesia.

\section{Multi-stakeholder platforms for disaster risk reduction}

\subsection{Conceptual review}

MSPs increasingly receive a great deal of attention in literature. MSPs are researched and implemented in natural resource management in general (e.g. Lockwood et al., 2010) or in specific sectors, such as water (e.g. Leach et al., 2002; Warner, 2005, 2006; Pahl-Wostl, 2008; Moellenkamp et al., 2010; Hemmati, 2002b) and forests (e.g. Elbakidze et al., 2010; Christensen et al., 2008). There are three key elements of MSPs: "multi", "stakeholder" and "platform" (Warner, 2006). "Multi" refers to the diversity of stakeholders (Warner, 2006). "Stakeholders" are individuals, groups or organisations that have stakes or interests, directly or indirectly, in the resources or problems at hand (World Bank, 2007). "Platform" means "dialogues, fora, partnerships and learning alliances" (Warner, 2006).

The objective of an MSP is mainly to create a space for the empowerment and active participation of common stakeholders intending to search for solutions to a common problem (Faysse, 2006). This is further differentiated into three key strands: "a mechanism of alternative dispute resolution, for adaptive management and as a vehicle for democracy and emancipation" (Warner, 2006). It is expected that an MSP will create a space for better and more acceptable decisions than those made without stakeholder participation (Hemmati, 2002a) or through one-to-one negotiations (Warner, 2006). Furthermore, Bäckstrand (2006) added that MSPs can achieve positive outcomes provided that there are clear linkages between institutions, agreement, clear targets, accountability, and mechanisms of evaluation to assess processes.

There are, however, several challenges in implementing MSPs. Faysse (2006) identified five main issues affecting the implementation of MSPs. These are power relationships, platform composition, stakeholder representation and capacity for meaningful participation, mechanisms for decisionmaking, and the cost of creating a MSP. Faysse (2006) further identified that "unfavourable circumstances" for MSPs are social inequalities, a state with a political that structure is either too strong or too weak to support a MSP processes or decisions, disorganised stakeholder groups, and a lack of financial and technical capacities to implement MSPs.

\subsection{A proliferation of MSPs from a global to a local levels}

There is a proliferation of MSPs worldwide, especially within the UNISDR system. There is one global, seven regional, (Africa, the Americas, Arab States, Asia, Europe, the Pacific), and 75 national platforms (PreventionWeb, 2011d). These are complemented with a multitude of thematic platforms, groups of DRR community with specific technical expertise focussing on the implementation of the HFA (include risk identification, vulnerability assessment, early warning, El Niño, drought, floods, water risks, wild land fire, environment, climate change, education, vulnerability assessment, disaster recovery, and capacity development) (UNISDR, 2012b). In Indonesia there are approximately 8 documented MSPs: 1 national; 3 local, mostly established in high-risk and frequently disaster-affected areas such as Aceh, Padang and Yogyakarta; a university forum; an education thematic platform at the national level; and thematic platform focussing on particular regional hazards, for example, the Merapi Volcano Forum and the Bengawan Solo River Forum (UNDP Indonesia, 2008).

Ten MSPs were selected for this study, three at the international level, two at the regional level and five MSPs from Indonesia. Consistent with the study's goal to explore the interlinkages of the MSPs and to examine the extent by which the global and regional MSPs facilitate the Indonesian MSPs in implementing DRR, the 10 MSPs are selected to capture diversity along the following dimensions: (a) they have strong progress at their respective level, (b) they have different mandates and roles, (c) they have the most diverse memberships, including governments, international organisations, non-government organisations (NGOs) and funding organisations, and (d) these MSPs have strong links to the selected Indonesian MSPs. 
Table 1. List of organisations included in the interviews on MSPs in Indonesia.

\begin{tabular}{|c|c|c|c|c|}
\hline No & Organisation & Category & Role & Level of operations \\
\hline 1. & BAPPENAS & Government & National Development Planning Agency & National \\
\hline 2. & BNPB & Government & National Disaster Management Agency & National \\
\hline 3. & The World Bank & Funding organisation & Funding for DRR and CCA & National \\
\hline 4. & UNDP & UN & Funding for DRR and CCA & National \\
\hline 5. & $\begin{array}{l}\text { SCDRR (Safer } \\
\text { Communities } \\
\text { through Disaster } \\
\text { Risk Reduction) }\end{array}$ & Multi-stakeholder & DRR projects & National \\
\hline 6. & $\begin{array}{l}\text { Indonesia National } \\
\text { Platform (Planas } \\
\text { PRB) }\end{array}$ & Multi-stakeholder & National Platform for DRR & National \\
\hline 7. & MPBI & $\mathrm{CSO}$ & DRR and CCA advocacy & National \\
\hline 8. & IFRC & $\begin{array}{l}\text { International } \\
\text { organisation }\end{array}$ & DRR and CCA advocacy & National \\
\hline
\end{tabular}

Table 2 lists the scale, year formed, members, goals and mandates as well as example of the MSPs' key activities. The three MSPs at the international level vary in mandates, memberships, and activities. The Global Platform (GPDRR) is the foremost forum for stakeholders working, researching, planning and implementing DRR (UNISDR, 2012c). It is a nonbinding declaration of intent that focuses on the vulnerability and resilience of a population or territory, rather than on the nature and intensity of the hazard. The Global Network for Disaster Reduction (GNDR) is initiated, run and coordinated by NGOs, civil society and community-based organisations to strengthen their roles in working together to improve the lives of disaster-affected communities (GNDR, 2011a). The Global Facility for Disaster Reduction and Recovery (GFDRR) operates as a financial institution that comprises donor countries and international organisations under the coordination of the World Bank (GFDRR, 2011). It is a financial mechanism and a partnership which leverage technical ability together with funding support (GFDRR, 2012g).

The Asian Regional Platform (ARPDRR) and the Asian Cooperation on Disaster Management (ACDM) are the largest and most diverse gathering of DRR organisations in the region. The ARPDRR acknowledges both the Asian Ministerial Conference on DRR (AMCDRR) and the ISDR-Asia Partnership (IAP), an informal group that aims to promote regional coherence and DRR coordination in the Asia region (UNISDR-AP, 2010). The ACDM is under the auspice of the ASEAN to accelerate and synergise DRR activities and improve diplomacy among the members (ACDM, 2009). Though ACDM is an ASEAN inter-governmental process, this study considers it a MSP due to the importance of committee in the region and active involvement other international partners in ACDM meetings and activities. Indeed, the UNISDR states that Inter-governmental collaboration is key to addressing DRR at a regional level (PreventionWeb, 2011a).
All Indonesian MSPs are created to improve the DRR coordination in the country. The National Platform aims to help coordinating DRR stakeholders in Indonesia and to influence national government policies (Planas PRB, 2009). The UNTWG-DRR was formed in 2002 to improve UN coordination to promote and facilitate DRR in Indonesia (UNTWG, 2006a). The CDE is a thematic platform to coordinate DRR stakeholders working on disaster education and advocate for disaster education consideration within Indonesian curriculum (UNTWG, 2008). Locally, the Yogyakarta Forum is a collaboration space for DRR stakeholders in Yogyakarta (YLPDRR, 2011), while the Merapi Forum (20062008) encompasses two local governments and NGOs working in the aftermath of the Merapi volcanic activity (UNDP Indonesia, 2008).

\section{Analysis}

\subsection{Multi-stakeholder platforms as a way to implement adaptive governance}

Different schools of thought influence the development of adaptive governance (AG) theories. Holling (1978) introduced his works on social-ecological systems and adaptive management, which was developed further into the notion of cooperative management and collaborative governance (e.g. Plummer and Fennell, 2009; Carlsson and Berkes, 2005). Then the concept of adaptive co-management is developed, combining adaptive management and cooperative management (Olsson et al., 2004). One major theoretical contribution to AG literature stems from the works of Ostrom and colleagues who extensively explore issues of common pool resources, polycentricism and adaptive governance of complex systems (Dietz et al., 2003; Brunner et al., 2005; Ostrom, 1990). Some of the more current studies are on multi-level governance (Hooghe and Marks, 2003), new 
Table 2. Multi-stakeholder platforms for disaster risk reduction from a global to a local level.

\begin{tabular}{|c|c|c|c|c|}
\hline No & Platform & $\begin{array}{l}\text { Scale/ } \\
\text { year formed/ } \\
\text { members }\end{array}$ & Goal(s)/Mandate(s) & Example of key activities \\
\hline 1. & GPDRR & $\begin{array}{l}\text { Global/ } \\
2005 / \\
152 \text { governments and } 137 \text { or- } \\
\text { ganisations }\end{array}$ & $\begin{array}{l}\text { To sustain worldwide momen- } \\
\text { tum to build the resilience of } \\
\text { nations and communities to dis- } \\
\text { asters }\end{array}$ & $\begin{array}{l}\text { Has held } 3 \text { meetings since } 2007 \\
\text { Supports } 6 \text { regional and } 78 \text { national } \\
\text { platforms }\end{array}$ \\
\hline 2. & GNDR & $\begin{array}{l}\text { Global/June 2007/ } \\
78 \text { NGOs/CSOs (community- } \\
\text { based groups, national and in- } \\
\text { ternational NGOs, research in- } \\
\text { stitutions) }\end{array}$ & $\begin{array}{l}\text { To work together to improve the } \\
\text { lives of people affected by dis- } \\
\text { asters worldwide }\end{array}$ & $\begin{array}{l}\text { "Views from the Frontline" (global } \\
\text { and independent measurement of HFA } \\
\text { progress at the local level) } \\
\text { "Actions at the Frontline" } \\
\text { "Texts from the Frontline" }\end{array}$ \\
\hline 3. & GFDRR & $\begin{array}{l}\text { Global/ } \\
2006 / \\
38 \text { countries and } 7 \text { international } \\
\text { organisations }\end{array}$ & $\begin{array}{l}\text { To help developing countries } \\
\text { particularly those identified as } \\
\text { the most vulnerable to natural } \\
\text { disaster to enhance their capac- } \\
\text { ity for DRR. }\end{array}$ & $\begin{array}{l}\text { Track I : to enhance global and regional } \\
\text { partnerships } \\
\text { Track II: to mainstream DRR into de- } \\
\text { velopment } \\
\text { Track III: standby recovery financing } \\
\text { facility }\end{array}$ \\
\hline 4. & ARPDRR & $\begin{array}{l}\text { Asia/ } \\
2003 / \\
37 \text { active institutions (donors, } \\
\text { IGOs, CSOs, UN, international } \\
\text { organisations, and media) }\end{array}$ & $\begin{array}{l}\text { To improve regional coordina- } \\
\text { tion and coherence in DRR ac- } \\
\text { tivities and HFA implementa- } \\
\text { tions }\end{array}$ & $\begin{array}{l}\text { The AMCDRR is the "political arm" } \\
\text { and the ISDR-Asia Partnership (IAP) is } \\
\text { the action arm } \\
\text { AMCDRR has been held four times } \\
\text { since } 2005 \text {. }\end{array}$ \\
\hline 5. & ACDM & $\begin{array}{l}\text { Southeast Asia/ } \\
2003 / \\
10 \text { ASEAN member states and } \\
\text { partners (UN, OCHA, UN- } \\
\text { HCR, UNICEF, IFRC, ADPC, } \\
\text { ADRC) }\end{array}$ & $\begin{array}{l}\text { To accelerate and synergise } \\
\text { DRR activities, foster dialogue, } \\
\text { promote confidence and pre- } \\
\text { ventive diplomacy }\end{array}$ & $\begin{array}{l}\text { ASEAN Disaster and Emergency Re- } \\
\text { sponse } \\
\text { ASEAN Coordinating Centre for Hu- } \\
\text { manitarian Assistance } \\
\text { ASEAN Regional Programme on DM } \\
2004-2010\end{array}$ \\
\hline
\end{tabular}

environmental governance (Holley et al., 2011) or adaptive governance of social-ecological systems (Folke et al., 2005).

The relationships between AG and DRR is explored in detail by Djalante et al. (2011), utilising resilience to bridge the two concepts together. The application of resilience in DRR studies gained worldwide interest specifically after the adoption of the concept in the HFA. Resilience is interpreted essentially as the ability to self-organise, learn and adapt (Carpenter et al., 2001). It is researched, applied and understood differently in different schools of thought (Djalante and Thomalla, 2011; Manyena, 2006; Klein et al., 2003). Holling (1973) pioneered the application of resilience in the field of ecology, while other scholars examined engineering resilience (e.g. Wildavsky, 1988), economic resilience (e.g. Rose, 2007) or social-ecological resilience (Folke, 2006). Resilience in DRR matters, not only as an outcome, but also as a process (Djalante and Thomalla, 2011), is measured differently (e.g. Bruneau et al., 2003), and needs to be considered as an integrated approach (e.g. Paton and Johnston, 2006) of disaster preparedness (e.g. Paton and Johnston, 2001), mitigation (Tobin, 1999), emergency management and response (Van der Torn and Pasman, 2008) to recovery (CCE, 2000). There are also large volumes of DRR literature that offer frameworks on how to build community resilience (e.g. Cutter et al., 2008; Norris et al., 2008; US/IOTWS, 2007; IFRC, 2008; Twigg, 2007).

Djalante et al. (2011) suggested four AG characteristics that are important for disaster resilience: polycentric and multi-layer institutions, participation and collaboration, selforganisation or flexible networks, and learning and innovation (see Fig. 1). They stated that polycentric and multilayer institutions are considered the most important factor in this depiction. This particular institutional arrangement, supported by leadership, trust and social capital, is crucial for participation and collaboration. They further suggested that self-organisation could be materialised formally or informally in different types of arenas and networks. These networks could help enhance learning and innovation, and ultimately create supporting environments for building disaster resilience (Djalante et al., 2011). 
Table 2. Continued.

\begin{tabular}{|c|c|c|c|c|}
\hline No & Platform & $\begin{array}{l}\text { Scale/ } \\
\text { year formed/ } \\
\text { members }\end{array}$ & Goal(s)/Mandate(s) & Example of key activities \\
\hline 6. & $\begin{array}{l}\text { Indonesia } \mathrm{Na}- \\
\text { tional Platform }\end{array}$ & $\begin{array}{l}\text { National/ } \\
\text { 2009/ } \\
\text { Government, CSOs, academia, } \\
\text { international communities, me- } \\
\text { dia, private organisations }\end{array}$ & $\begin{array}{l}\text { To support and facilitate coop- } \\
\text { eration among stakeholders on } \\
\text { DRR in Indonesia }\end{array}$ & $\begin{array}{l}\text { Advocacy on policy, planning and insti- } \\
\text { tutions, promoting educations for DRR } \\
\text { Involved in HFA progress reviews } 2009 \\
\text { and } 2011\end{array}$ \\
\hline 7. & UNTWG-DRR & $\begin{array}{l}\text { National/ } \\
\text { 2002-2010/ } \\
\text { OCHA and UNDP are the co- } \\
\text { chairs }\end{array}$ & $\begin{array}{l}\text { To improve coordination and } \\
\text { enhance the UN roles in pro- } \\
\text { moting and facilitating DRR }\end{array}$ & $\begin{array}{l}\text { Convergence Group } \\
\text { Aceh and Nias recovery and reconstruc- } \\
\text { tion } \\
\text { Capacity building }\end{array}$ \\
\hline 8. & $\begin{array}{l}\text { Consortium for } \\
\text { Disaster Educa- } \\
\text { tion }\end{array}$ & $\begin{array}{l}\text { National/ } \\
2006 / \\
48 \text { NGOs }\end{array}$ & $\begin{array}{l}\text { To coordinate various actors on } \\
\text { DRR education in Indonesia }\end{array}$ & $\begin{array}{l}\text { Advocacy for the integration of DRR } \\
\text { within the school curriculum } \\
\text { Drafting of disaster education main- } \\
\text { streaming }\end{array}$ \\
\hline 9. & $\begin{array}{l}\text { Yogyakarta Fo- } \\
\text { rum for DRR }\end{array}$ & $\begin{array}{l}\text { Sub-national (Province)/ } \\
2009 / \\
38 \text { local government agencies, } \\
40 \text { NGOs }\end{array}$ & $\begin{array}{l}\text { To serve as platforms for all } \\
\text { stakeholders concerned with } \\
\text { DRR in Yogyakarta }\end{array}$ & $\begin{array}{l}\text { Emergency management: Merapi vol- } \\
\text { cano eruption (2010) } \\
\text { Yogyakarta DM Guidelines and Action } \\
\text { Plan for DRR 2011-2013 }\end{array}$ \\
\hline 10. & Merapi Forum & $\begin{array}{l}\text { Local/ } \\
2006-2008 / \\
4 \text { local governments, } 8 \text { NGOs } \\
\text { and international organisations }\end{array}$ & $\begin{array}{l}\text { To increase synergy and collab- } \\
\text { oration among the local govern- } \\
\text { ments and other organisations }\end{array}$ & $\begin{array}{l}\text { This is a good example of ecosystem- } \\
\text { based management for DRR } \\
\text { Emergency management: Merapi erup- } \\
\text { tion (2006) }\end{array}$ \\
\hline
\end{tabular}

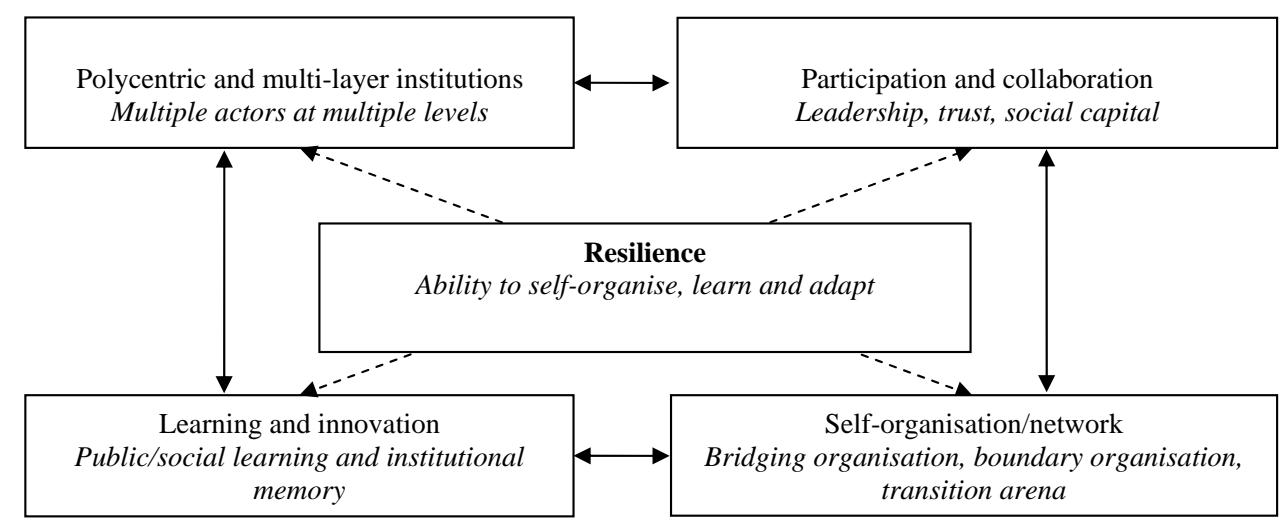

Fig. 1. Relationships between adaptive governance and resilience (Source: Djalante et al., 2011) ${ }^{1}$

The following sub-sections interrogate the MSPs in relation to each of the four characteristics to help answer the first question of the paper on how MSPs are formed, organised and coordinated. Each sub-section systematically discusses the MSPs from a global, regional, national and local level.

\footnotetext{
${ }^{1}$ Solid line arrows represent the main relationships, while the dashed lines represent the indirect relationships between the characteristics.
}

\subsubsection{Polycentric and multi-layer institutions: how do multi-stakeholder platforms complement existing forms of governance for disaster risk reduction?}

McGinnis (1999) states that polycentric government systems essentially involve different types of governing authorities at various levels, by which in such systems, many of the roles previously held by a central government are now carried out by non-state actors, including administration, regulation, management and mediation. One of the most notable 
characteristics of MSPs is that they comprise various organisations: government, non-government, local and international agencies. This is a significant step toward greater involvement of non-government entities in DRR planning and implementation in a traditionally government-driven activity.

Table 3 summarises the key events in the MSPs development. DRR received international attention in the early 1990s. The UN declared the period as the International Decade for Natural Disaster Reduction (IDNDR), driven by the increasing impacts of disasters on human casualties as well as property and economic damage in the 1980s (United Nations, 1989). One of the IDNDR outcomes was the adoption of the "Yokohama Strategy for a Safer World: Guidelines for Disaster Prevention, Preparedness and Mitigation" during the UN World Conference on Natural Disaster Reduction (WCDR) in 1994 (IDNDR, 1994). It was a big shift in the disaster management paradigm from prevention to preparedness and mitigation. The Yokohama strategy called for systematic and comprehensive vulnerability reduction and stakeholder involvement including those who are the most vulnerable. Therefore, the role of technology supported by a strong political commitment to reduce disaster risk needs to be pushed forward (IDNDR, 1994). The early period of the MSP establishment progressed mainly at the international level. In 1999, the International Strategy for Disaster Reduction (ISDR) was established to support DRR efforts internationally (UNISDR, 2011d). In lieu of the ISDR formation, multi-stakeholder collaborations were initially implemented through the formation of the Inter-Agency Task Force on Disaster Reduction (IATF-DR) (UNISDR, 2000a). The development of the IATF-DR created a shift in the management of DRR. The mandated was intended to serve as the main forum within the UN systems in DRR and to convene ad hoc meetings of experts on issues on DRR (UNISDR, 2000b). During the period of 2000-2005, the members included the Under-Secretary-General for Humanitarian Affairs and the Director of the ISDR Secretariat, $16 \mathrm{UN}$ agencies/organisations/programmes, 10 regional entities and 8 civil society organisations (UNISDR, 2000a).

The year 2005 marked the enormous progress on the establishment of key frameworks and institutions for DRR following the establishment of the UNISDR systems. The HFA was adopted during the 2005 WCDR in Kobe (UNISDR, 2005). The UNISDR established the Global Platform as the successor for the IATF-DR (UNISDR, 2011b). The GFDRR was later formed in 2006 as the key financial institutional support which also build partnerships and leverage technical capacity in DRR for the recipient countries (GFDRR, 2011). The formation of this Global Platform marked the greater and more extensive involvement of stakeholders beyond those originally involved in the IATF-DR. Through the UNISDR system, regional platforms are established worldwide (Africa, the Americas, Arab States, Asia, Europe, the Pacific) (PreventionWeb, 2011b). Further, the global and regional platforms conduct more reported activities than na- tional platforms. Based on data from PreventionWeb, by October 2011 there have been seven key events, two regional ministerial meetings, four regional HFA progress reports and 13 key documents submitted (PreventionWeb, 2011c). These events, meetings and documents exhibit considerably uniform progress among the six regional platforms. The operation of the Asia Regional Platform involves building and gathering support from sub-regional institutions such as the south Asian Association for Regional Cooperation, the ASEAN Secretariat and the Secretariat of the Pacific Community (UNISDR-AP, 2010).

Currently, 78 out of the 224 nations and territories involved in the Global Platform have their own national platforms (PreventionWeb, 2011d). However, only seven (Indonesia, Iran, the Philippines, Colombia, China, Sri Lanka and Afghanistan) of the 15 countries with the greatest risk according to the Natural Disaster Risk Index 2010 (Maplecroft, 2010) have their own national platforms (PreventionWeb, 2011d). The structures of the MSP at the national level vary across countries: some national platforms are parts of governments, while others are not. For example, of the 18 national platforms established in Europe, two are NGOs and 15 are governmental bodies, while France combines the two (UNISDR, 2011f). In Asia, there are only seven countries (China, Japan, Iran, the Philippines, Sri Lanka, Kazakhstan and Indonesia) that have formally established their national platforms (UNISDR, 2009b). The establishment of national platforms was requested in an UN Economic and Social Council Resolution (ECOSOC) resolution of 1999/63 and in three General Assembly resolutions of A/RES/56/195, A/RES/58/214 and A/RES/58/215 (UNISDR, 2011h). The ECOSOC 1999/63 "called on all Governments to maintain and strengthen established national and multi-sectoral platforms for natural disaster reduction in order to achieve sustainable development goals and objectives, with the full utilisation of scientific and technical means". This is complemented with the UN General Assembly Resolution A/RES/59/231 in 2005 which "called upon governments to establish national platforms or focal points for disaster reduction, encouraged government to strengthen platforms where they already exist, urged United Nations system to provide appropriate support to those mechanisms" (UNISDR, 2011h).

The interview with the Indonesian National Platform representative stated that the platform's 2009 organisational structure consists of a directing board (3 members), supervising board ( 3 members), executive board ( 5 members) as well as 5 coordinating sections on institutions and organisations, education, information and public awareness, partnerships and capacity development. Personnels filing in the structure represent BNPB (The National Disaster Management Agency), the Indonesian Red Cross, several UN organisations (UNDP, UNESCO), universities, international and national NGOs as well as those from media and private agencies (MPBI, 2011). This structure was revised in 2011, con- 
Table 3. Important timelines for multi-stakeholder platforms from global to local scale.

\begin{tabular}{|c|c|}
\hline Year & Activities \\
\hline 2012 & -5th AMCDRR to be held in Yogyakarta, Indonesia \\
\hline 2011 & $\begin{array}{l}\text {-Third Session of the GPDRR meeting in Geneva, hosted concurrently with the } \\
\text { World Bank for the World Reconstruction Forum } \\
\text {-Indonesian President received the honour of "The Global Champion for DRR" } \\
\text { from the UN Secretary General } \\
\text {-HFA Mid-Term Review -ARF DiRex disaster relief exercise in Manado, In- } \\
\text { donesia } \\
\text {-The Japan Earthquake, Tsunami and Fukushima Nuclear Crisis }\end{array}$ \\
\hline 2010 & $\begin{array}{l}\text {-4th AMCDRR meeting in Incheon, Korea on DRR and CCA integration, re- } \\
\text { sulted in Incheon Declaration } \\
\text {-The ACDM adopted the AADMER work programme for 2010-2015 } \\
\text {-AHA Centre created and centred in Indonesia } \\
\text { - Mt Merapi volcanic eruption in Yogyakarta, Indonesia }\end{array}$ \\
\hline 2009 & $\begin{array}{l}\text {-Second Session of the GPDRR meeting in Geneva: Creating Linkages for a } \\
\text { Safer Tomorrow } \\
\text {-1st GAR report on DRR launched } \\
\text {-Indonesia National Platform established } \\
\text {-Yogyakarta Provincial Platform for DRR formed }\end{array}$ \\
\hline 2008 & $\begin{array}{l}\text {-3rd AMCDRR meeting in Kuala Lumpur (KL declaration on MSPs for DRR) } \\
\text {-Cyclone Nargis in Myanmar }\end{array}$ \\
\hline 2007 & $\begin{array}{l}\text {-First Session of GPDRR meeting in Geneva: Acting with common purpose } \\
\text {-GNDR was officially launched during the GPDRR meeting } \\
\text {-AMCDRR 2nd meeting in New Delhi, India, which adopted AMCDRR as the } \\
\text { "political arm" and the ISDR-Asia Partnership (IAP) as the "action arm" of the } \\
\text { Asian Platform }\end{array}$ \\
\hline
\end{tabular}

sisting of 9 members of the directing board and 26 for the implementing board (BNPB, 2011b). In total, the representatives are comprised of 3 governments, 4 academies and universities, 13 civil societies and national NGOs, 2 media, 5 business, 1 red-cross and 6 religious based organisations, which show more involvement of national NGOs as well as private organisations than the 2009 structure. The local MSPs in Indonesia seemed to still be nominated by local government agencies that have responsibility for directing, managing and financing DRR programmes and activities. Hence, the local MSPs do not appear to play a greater role beyond those that are supposed to be government responsibilities. The activities are also project based, implemented and finance through a international project, following high scale disasters. For example, the Yogyakarta platform is developed through the SCDRR project. Yogyakarta is one of the six priority locations for the project, especially following the 2006 and 2010 earthquakes and volcanic eruptions (SCDRR, 2008). Bappeda (the local planning agency) leads the platform and holds the secretariat (YLPDRR, 2011).

In summary, the MSPs are to some extent able to complement DRR activities beyond what is traditionally the responsibility of governments. MSPs bring new nuance by which inclusion and participation of other agencies is recognised, strengthened and enhanced. This, however, tends only to happen at the global, regional and national level. At the local level in Indonesia, the role of the MSPs seems to be on the administrative and structural sphere only, and the extent to which they influence decision making in DRR planning and implementation is still unclear.

\subsubsection{Participation and collaboration: to what extent are these multi-stakeholder platforms inclusive of diverse members of society?}

One of the underlying reasons for the formation of MSPs is to enable better participation and coordination, especially among diverse members of civil society. Figure 2 shows the number of NGOs and government organisations represented in different MSPs, which demonstrates the importance of NGOs and other international organisations that have been considered important players and have taken on major roles in building disaster resilience worldwide.

The highest level of involvement of these non-government entities is at the international level, especially within the GPDRR. NGOs comprise the entire network of GNDR, the Indonesia National Platform and CDE. Almost equal 
Table 3. Continued.

\begin{tabular}{ll}
\hline Year & Activities \\
\hline 2006 & -GFDRR established \\
& -CDE formed in Indonesia \\
& -Merapi Forum formed in Yogyakarta, Indonesia \\
& -Yogyakarta Earthquake \\
\hline 2005 & -UNISDR System established \\
& -Global Platform formed as the successor of the IATF/DR \\
& -WCDR conference, Kobe, Japan \\
& -The Hyogo Framework for Action 2005-2015: Building the Resilience of Na- \\
& tions and Communities to Disasters developed \\
& -GFDRR established; charter revised in 2010 \\
& -AMCDRR 1st meeting in Beijing \\
& -AADMER ratified by 10 ASEAN countries \\
& -UNTWG-DRR in Indonesia co-chaired by OCHA and UNDP \\
\hline 2004 & -ACDM developed an ASEAN Regional Programme on Disaster Management \\
& (ARPDM) 2004-2010 \\
& -The Indian Ocean tsunami \\
\hline 2003 & -IAP formed \\
& -ACDM established
\end{tabular}

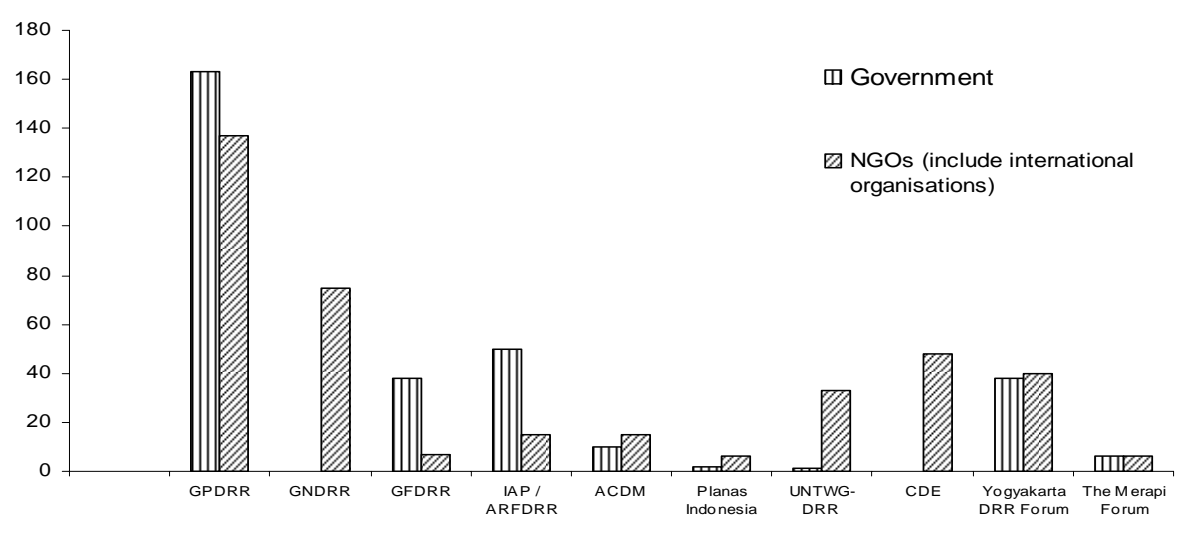

Fig. 2. Number of government and NGO members in different MSPs (source: calculated from GPDRR, 2011a; GNDR, 2012a; GFDRR, 2012g; ACDM, 2009; Planas PRB, 2009; UNTWG, 2006b; YLPDRR, 2011; UNDP Indonesia, 2008). 
representation between the government and NGOs is observed within the ACDM, Yogyakarta Platform and the Merapi Forum. The NGOs are comprised of mostly international and local NGOs, and to a lesser extent, media and private agencies. Active representation of NGOs as well as international and community-based organisations within the MSP is a positive step towards participation and collaboration. However, the way by which the organisations are involved and influence the decision-making processes is still not clear within the MSPs and for DRR in general.

\subsubsection{Self-organisation and flexible networks: Are these multi-stakeholder platforms actively mapped into broader networks of collaboration among other stakeholders?}

Networks are typically informal, self-organised governance systems, which can include a variety of actors from different organisational levels working together with a common purpose (Folke et al., 2005, p. 450). There are several examples by which the MSPs have actively mapped themselves into the broader network of inter-MSP collaboration. The IATF, formed in 2000, was considered the embryo of the GPDRR (UNISDR, 2000). The third meeting of the GPDRR was held concurrently with the World Reconstruction Forum, hosted by the World Bank and the GFDRR (UNISDR, 2011h). The GNDR is another example of self-organisation in MSPs, as it provided an avenue through which the NGOs involved in the GPDRR could strengthen their presence and voice as well as giving NGOs stronger representation at the grassroots level (GNDR, 2012a).

Rather than creating new entities with similar functions, the Asia Ministerial Conference (AMCDRR) was adopted as the "political arm" of the Asia Regional Platform on DRR, and the IAP was adopted as its "action arm" (UNISDR-AP, 2010, p. 11). The Asia partnership functions were revised in 2005 to also serve as the UNISDRR-managed Asia Regional Platform for DRR (UNISDR-AP, 2010).

The formation of the Indonesia National Platform was, to a certain extent, facilitated by the already established Convergence Group, managed by the UNTWG-DRR. Moreover, the CDE is the education working group within the Convergence Group. Most Merapi Forum members then became actively involved in the Yogyakarta Platform for DRR (YLPDRR, 2011).

The above discussions show that the MSPs, to certain degree, actively mapped themselves into the broader network of inter-MSP collaboration. What is needed now is a greater capacity for the MSPs to be able to strengthen their internal capacities so that they can take advantage of the opportunities to implement their mandates and purposes.

\subsubsection{Learning and innovation: how do experiences from past disasters affect the development and op- eration of the multi-stakeholder platforms?}

Lave and Wenger (1991) define learning as the process of active social participation and dynamic integration of people with their environment to construct meaning and identity. Table 3 shows some key activities undertaken by the selected MSPs, complemented with key events influencing DRR planning and policies. Several key disaster events highly influenced the development of MSPs in Indonesia, Asia and also globally: the 2004 Indian Ocean tsunami, the Yogyakarta earthquake and Merapi volcanic eruption, and lately the Great Tohoku triple disaster of earthquake, tsunami and nuclear crisis in Japan.

The Indian Ocean tsunami in 2004 affected 13 countries mostly in Asia and Indonesia was impacted by the tsunami the most. There were 165708 deaths, almost 533000 people affected, and costed US\$ 4451600000 damage to the country (EM-DAT, 2012). The catastrophic tsunami elevated awareness as well as created greater political commitment for DRR, globally and especially in the Asian region.

In Asia, the AMCDRR first meeting was held in 2005, as the official international conference of ministers and experts involved in disaster management in Asia. The 10 southeast Asian countries involved in ACDM immediately adopted and ratified the ASEAN Agreement on Disaster Management and Emergency Response (AADMER) (ASEAN, 2005). The ASEAN Secretary stated in his speech in the 2005 Asian Leadership Conference in Seoul that the experience of the first regional collective disaster response following Cyclone Nargis in Myanmar in 2008 has led to the realisation that ASEAN must strengthen its regional DRR mechanisms through AADMER (Yong, 2005). The Secretary further added that ASEAN would continue learning from various experiences of responding to, managing and recovering from current disasters in the region, and also expressed ASEAN willingness to share those experiences with neighbouring regions (Yong, 2005).

Some of the initiatives taken within the ACDM are influenced by the progress of similar initiatives in ASEAN countries, especially Indonesia. For example, the AADMER, the AHA and also the ARF DiRex are located or held in Indonesia (Kamal, 2010). The establishment of the UNTWG-DRR in 2002, to improve coordination among the UN organisations in Indonesia, marked the recognition of the importance of MSPs in increasing coordination for DRR (UNTWG, 2006a). It was originally managed by The Office of Coordinating Humanitarian Affairs (OCHA), and later co-chaired with the United Nations Development Program (UNDP), after the 2004 Indian Ocean tsunami (UNTWG, 2006a). In subsequent years, the Indonesia National Platform was formed. Following the Yogyakarta earthquake and Merapi volcanic eruption, both the local MSPs were created (UNISDR-AP, 2010). 
Referring back to the question of how experiences from past disasters affect the development and operation of MSPs, the author has shown that the understanding is taking place between the MSPs. Large scale or high impact disasters which frequently hit Asia and Indonesia created and brought enormous changes to DRR systems for the increased political commitments to the DRR institutions and frameworks. However, the author sees the need for more systematic learning from disaster experiences, a term that is frequently termed single, double and triple loop learning (Argyris and Schoen, 1974). Many studies in DRR express the need for (Jabeen et al., 2010; Goldstein, 2008; Josef, 2007; Voss and Wagner, 2010; Farazmand, 2007) systematic learning from disasters. This is also the case in Indonesia, whereby a finding from another paper (Djalante et al., 2012) found that the abundance of material published on lessons learned from the 2004 tsunami are not accessible to most of the decision makers at the local government level, nor is it evident that the systematic learning system is developed locally.

To summarise Sect. 4.1, the discussion in each of the three questions show that MSP can be considered a mechanisms that allow for the implementation of AG. The MSPs are organised through polycentric and multi-layered institutions from the global to the local level. They are often formed through reorganisation or previous entities created with similar purposes. MSP members are largely comprised of government agencies and international as well as nongovernment organisations. There is, though limited, evidence that shows learning and innovation is taking place; however, some challenges remaining, which include involvement of non-government entities within the DRR decision-making processes and the extent by which the operation the MSPs can influence the processes, the strengthening of the mandate, the function of the MSPs, and the need for systematic learning from past disaster experiences.

\subsection{Roles, interlinkages and collaborations between the multi-stakeholder platforms to build disaster resilience}

This sub-section presents the author analysis on the roles, interlinkages and collaborations between the MSPs, utilising Biermann et al. (2007) framework on partnership implementation. Figure 3 shows the relationships between the selected MSPs, horizontally (on the same geographical scale) and also vertically (across different scales). The arrows represent different activities and types of support between the MSPs: financial resources, technical capacity and assistance in DRR coordination. In general, there are more horizontal connections at the global level while the vertical relationships between the MSPs have mainly developed along the lines of the formation of the GPDRR, and the supporting regional, national and local MSPs, as part of the UNISDR system.

\footnotetext{
${ }^{2}$ Arrows - full arrow: involvement in management, dotted arrow: financial support, dashed arrow: partnerships and coordination
}

The next section discusses the roles, interlinkages and collaborations between the MSPs, and in particular, the extent by which the global and regional MSPs support the Indonesian MSPs in building disaster resilience.

\subsubsection{Do the multi-stakeholder platforms have the re- quired capacity to implement their programmes and support other MSPs?}

MSPs at the international level tend to have enormous human and technical capacity to implement their intended purposes and to support other MSPs. The GPDRR is the world's largest gathering of DRR stakeholders. During its third session in 2011, there were over 2600 delegates representing 163 governments, 25 intergovernmental organisations (IGOs) and 65 NGOs as well as parliamentarians, representatives of the private sector, members of local government, academics, civil society members and international organisations (UNISDR, 2011h). It was created as part of the UNISDR's mandate to be the focal point within the UN systems in coordinating and ensuring synergies among DRR activities (UNISDR, 2011b). This mandate is implemented through four key activities: coordinating, campaigning, advocating and informing different aspects of DRR (UNISDR, 2011b).

The GNDR membership currently includes a broad range of organisations, such as CBOs, national and international NGOs, and academic and research organisations (GNDR, 2012b). The GNDR activity on the ground has received a "Letter of Commendation" from the UN Sasakawa Award Jury, confirming the GNDR's ability and capacity for networking and coordination of local organisations (GNDR, 2011a). In its worldwide surveys of "Views from the Frontline", GNDR had been able to mobilise 20000 people in 69 countries, with over 90 case studies presented (GNDR, 2012b). Following these surveys, other world scale activities were conducted, such as "Action at the Frontline" (GNDR, 2012c) and "Text from the Frontline" (GNDR, 2012c).

These global scale MSPs are closely linked and seem to support each other strongly. The UNISDR, as the coordinator for the GPDRR, has strongly supported the GNDR in various ways. It facilitated the official launch of the GNDR during the first GPDRR meeting in 2007 (GNDR, 2012a). It has further facilitated and connected the GNDR with other civil society networks and intergovernmental stakeholders on DRR within the UNISDR system. The UNISDR also provide and exchange DRR-related information that is of high concern to NGOs and CSOs (GNDR, 2012a). The UNISDR also highly supports the GNDR global scale surveys of the HFA "Views from the Frontline" report, which focuses on NGO and community views on HFA effects at the grassroots level (GNDR,

support, curved arrow: influence in policy formulation, dash-dot arrows: supports to increase technical capacity. Shapes - Full square box: current MSP, dashed square box: the MSP has ceased operation. 


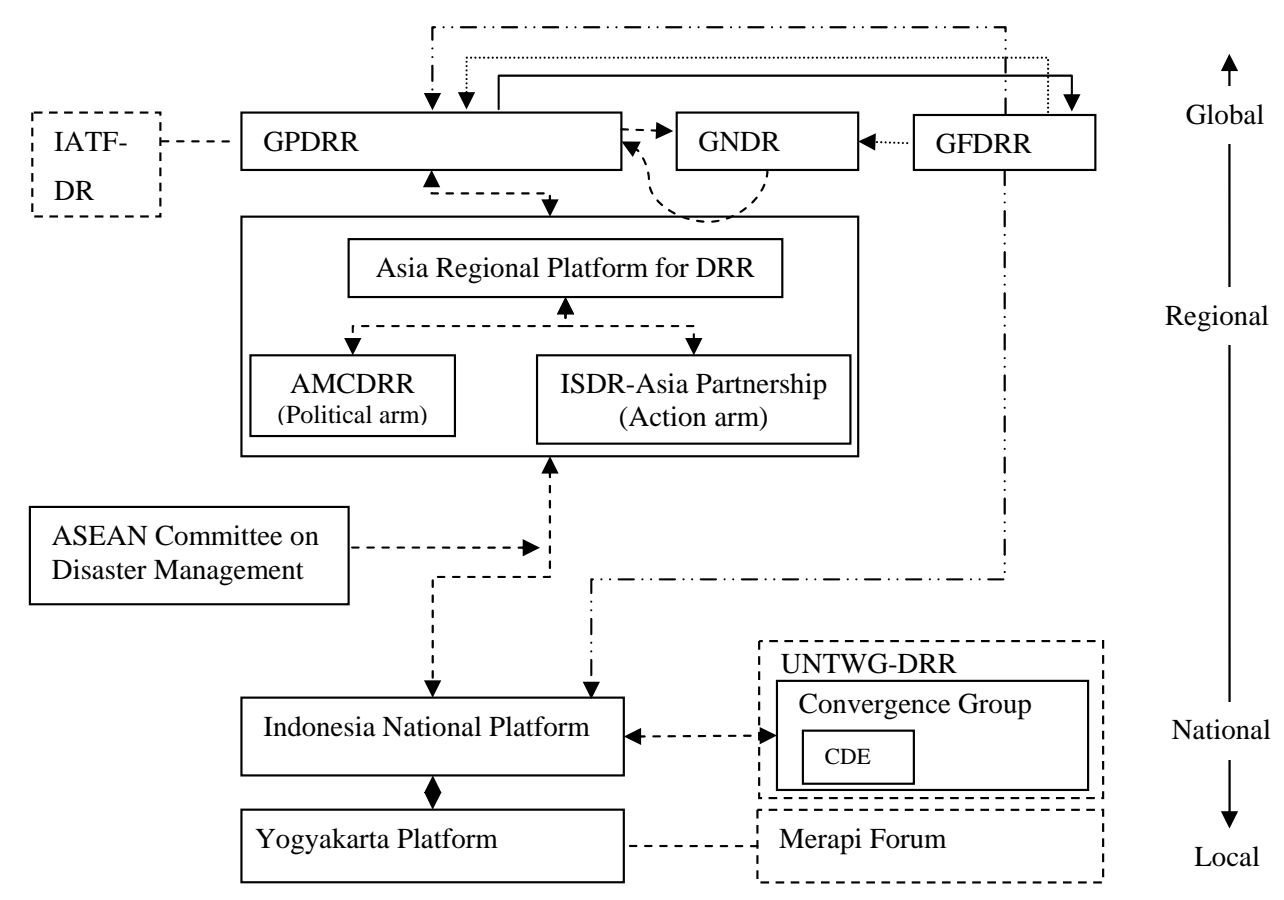

Fig. 3. Relationships between selected MSPs. ${ }^{2}$

2012c). Conversely, the results of these surveys significantly influence the directions of UNISDR's DRR policies and their implementation, focusing on HFA implementation at the local level (UNISDR, 2011j).

The GPDRR also works closely with the GFDRR, especially within its governance structure. Along with representatives from donor and recipient countries, the chair of the International Strategy for Disaster Reduction (ISDR) system is part of the GFDRR consultative group. The director of the ISDR secretariat is part of the GFDRR's Result Management Council (GFDRR, 2012b). There are three main tracks of GFDRR operations: track I refers to global and regional partnerships, track II refers to mainstreaming DRR in development and track III refers to disaster recovery funds (GFDRR, 2012e). Track I is run jointly with the UNISDR, by which since 2007 US $\$ 5$ million has been allocated annually to support UNISDR's activities in improving partnerships of a wide range of DRR stakeholders, including governments, the UN, multilateral banks, regional organisations and civil society partners (GFDRR, 2012f). Another connection at the global level is between the GNDR and the GFDRR. The GFDRR has contributed US $\$ 150000$ to the Global Network's operations (GNDR, 2012b).

The supports received by the Global Platform from the UNISDR also evolve regionally, by which the UNISDR highly support the operation of the Asian Regional Platform, which include the AMCDRR and the IAP. These regional MSPs received technical, coordination and financial support from the UNISDR and the GPDRR (UNISDR, 2012c). For example the UNISDR and its Asia-Pacific secretariat have helped the IAP to run and organise AMCDRR meetings since 2005, and the outcomes of these meetings were, in turn, used to inform discussions during the meetings of the GPDRR (UNISDR, 2012c).

The Indonesian National Platform presence in the regional and local MSPs is highly recognised. The interview with the SCDRR project representative stated that through SCDRR support, the National Platform actively attended and contributed to the three global platform meetings through presenting Indonesia's experience in the reconstruction processes following big disaster events. The Indonesian president Yudhoyono was also inaugurated as the "Global Champion for DRR" during the third Global Platform meeting (UNISDR, 2011h).

The in-depth interviews between all the respondents show that in Indonesia, there are strong horizontal relationships between the Convergence Group, CDE and the National Platform. The Indonesia National Platform as well as the Yogyakarta, Padang and Aceh local platforms were formed through the (SCDRR) project, and was implemented collaboratively by the Indonesian Government and the UNDP, and supported by the GFDRR (UNDP Indonesia, 2012). The SCDRR key informant stated that the support given to the MSPs includes financial and technical support in the initiation, formation and operation of the MSPs. For example, the SCDRR coordinated NGOs and financially supported the meetings leading to the formation of the Indonesia National Platform. 
Key personnel from BNPB explained that secretariat of the platform is hosted within the office of the BNPB; while the BNPB and Bappenas both have representatives in the Indonesia National Platform. Further, the interview with the key personnel from Bappenas (The National Development Planning and Coordination Board) stated that Bappenas, the World Bank, UNDP and National Disaster Management Agency (BNPB) were the key organisations involved in the project. The respondents expressed that the support to the MSPs demonstrated the Indonesian government's commitment to helping mainstream DRR within its development strategies, which were formally mandated stating that disaster and climate change issues are included in the Indonesian government's nine national development priorities. Furthermore, a strong government commitment to various DRR initiatives in Indonesia has also been facilitated by longstanding DRR operations by the UN in Indonesia, especially through various DRR operations run by the UNDP and the OCHA. In answering the author's question on platforms' technical capacity, the representative from the National Platform expressed the need for more technical and financial support especially on the need for a dedicated personnel and funding to support the day-to-day operation of the platform. Another issue raised was the lack of sectoral agencies involvement within the platform that hinders effective DRR coordination and resource provision by sectoral agencies.

In summary, the author has shown that the MSPs at different level have different capacities. MSPs at the international level tend to have enormous human and technical capacity to implement their intended purposes. It is not quite clear since there is no data available or accessible on how regional MSPs implemented their activities beyond coordination. In Indonesia, the MSPs tend to be project-based and their sustainability remains unclear should the projects cease operations.

\subsubsection{Do the multi-stakeholder platforms generate new sources of funding and to what extent do these funds evolve into other MSPs?}

MSPs at the international level tend to have higher capacity for generating funding to implement their intended purposes. The UNISDR's entire source of funding is through voluntary contributions, which are channelled through The United Nations Trust Fund for Disaster Reduction created in 2000 (UNISDR, 2012d). The UNISDR 2010 financial report stated that in total, US $\$ 28.6$ million has been contributed and expedited through the trust fund (UNISDR, 2010a). Out of this total amount spent, almost half of the funds were spent on regional work programmes, approximately one-third was spent on global work programmes, and the remainder was split between thematic works and management expenditure (calculated from UNISDR, 2010a). However, there is no data publically available on how much money is allocated to support these MSPs, globally to locally. The GFDRR is essentially a funding organisation, established in 2006 under the leadership of the World Bank. With the partnerships of 39 countries and eight international organisations, GFDRR's aim is to reduce vulnerability to hazards by mainstreaming disaster reduction and recovery in development strategies (GFDRR, 2010c). In its last six years of operation, GFDRR has received a total of US \$324 million from its 18 donor countries and organisation (Australia, Brazil, Canada, Denmark, European Commission, France, Germany, Ireland, Italy, Japan, Luxembourg, Norway, Spain, Sweden, Switzerland, the Netherlands, the United Kingdom and the United States) (GFDRR, 2012a). The fund was then distributed accordingly: 69 per cent was allocated to supporting mainstreaming DRR and CCA, 17 per cent was allocated to financing global and regional partnerships and 14 per cent was allocated for recovery (GFDRR, 2012b). The GNDR receives support from various donors, with the United States Agency for International Development and Swedish International Development Agency among its largest contributors. As of 2010, the GNDR has been able to secure almost US\$3.9 million in donor funding (GNDR, 2012b). There is no supporting data obtainable on how the GFDRR directly supports the local MSPs, nor data on the extent to which the national and local MSPs have secured funding from other organisations. In sum, the author suggests that the upper level MSPs tend to have better ability to generate and secure new sources of funding than their lower level counterparts. This is, however, based on the limited data obtained by the author. Transparency on use and availability of funding information is an important aspect that is systematically lacking amongst the large majority of MSPs.

\subsubsection{Do the multi-stakeholder platforms focus on direct effects in reducing disaster risks or target more vulnerable groups?}

Reducing the underlying risk factors requires the consideration of disaster risks into long-term development planning and disaster reconstruction. Disaster risks are complex interactions between social, economic and environmental conditions and land use, as well as the effects of geological, hydro-meteorological and climatic hazards (UNISDR, 2007b). There are some notable examples of MSP activities on this theme.

The GFDRR has demonstrated a great deal of commitment in financing DRR programmes and activities that reduce disaster risks, both directly and indirectly, through its tracks I, II and III funding. For example, the GFDRR spent almost US\$1.25 million on track II, "Mainstreaming DRR in Indonesia" (GFDRR, 2010a). The funds were spent on direct risk reduction projects, such as improved basin retention and an enhanced drainage and water supply system. The GFDRR has also conducted an initiative called the "South-South Cooperation Program", which directly targets the most vulnerable groups; in this case, low- and middleincome disaster-prone countries. In this project, the GFDRR 
distributed grants to create a partnership with three disasterprone cities (Makati, Philippines; Kathmandu, Nepal and Quito, Ecuador) and provided grants to three NGOs located in India, Guatemala and Honduras, focusing on women and DRR issues (GFDRR, 2012d). The GFDRR project in Indonesia has been implementing programmes strengthening regulatory provisions for earthquake-safe building codes (2011). Its other projects that indirectly reduce disaster risks include the formulation of key DRR planning documents, such as the National Action Plan for DRR and capacity building for DRR at the national and sub-national levels (GFDRR, 2010a). All respondents from the interview stated that through the support of the World Bank and UNDP, the Indonesia National Platform has been actively working with the BNPB and Bappenas in developing several key documents on DRR in Indonesia, namely the National Guidelines for DRR 2010-2014, the National Action Plan for DRR 2007-2009 and 2010-2012. At the local level, the Yogyakarta Platform has been working with the government of the Yogyakarta province in developing the Local Law on Yogyakarta Disaster Management (YLPDRR, 2011).

Emergency preparedness and response is another theme that has accorded high priority on the agenda of some MSPs. The GFDRR track III funding has been set-up as the "standby recovery financing facility" should any major disasters occur (2010b). Emergency management is also one of the main foci of the MSPs in the Asian and southeast Asian regions, through the formation of the ASEAN coordinating centre for Humanitarian Assistance (AHA centre) (ACDM, 2009). Through the AADMER, there is a provision for "Standby Arrangements for Disaster Relief and Emergency Response" to increase preparedness and improve management of emergencies (ASEAN, 2005). The Yogyakarta Platform formed the communication centre for emergency coordination concurrently with the local government during the Merapi eruption in 2010 (YLPDRR, 2011). The CDE is the only MSP that implements activities that aim to reduce disaster risks directly. The CDE has conducted extensive activities aimed at influencing policy, capacity building and training to increase awareness of disaster risks. For example, one of the key NGOs within CDE, the Kerlip foundation, has collaborated with the local government in the Cianjur district to conduct related workshops (UNISDR, 2010b).

In summary, GFDRR is the only MSP that is able to significantly conduct activities that are able to directly reduce risks and target more vulnerable populations. This is, however, understandable since the GFDRR is essentially a funding organisation with ability to secure and generate finances from other organisations.

To summarise Sect. 4.2, the discussion in each of the three questions above shows that there are strong linkages and collaboration among the MSPs. It was shown that international scale MSPs have greater technical and financial capacity to implement the intended programmes; hence, they are able to collaborate and support other MSPs. The Global Platform hold a key role in the operation, development and, most importantly, the coordination with other MSPs. MSPs at the regional level seem to focus their activities on better coordination of DRR actions and hence, there is no specific information on how they directly support MSPs at the national and local level. The SCDRR project in Indonesia has facilitated the development of the National Platform and the local platform in Yogyakarta. These actions, however, are still project based and externally supported as there are currently only two local governments (West Sumatra and Yogyakarta provinces) that have already developed their MSPs with the support from the SCDRR project (Planas PRB, 2009).

\section{Recommendations and conclusion}

\subsection{Recommendations}

The main finding derived from this study is that MSPs at the international and regional level tend to have more technical, financial and coordinating capacity than lower scale MSPs. Particularly for Indonesia, to encourage and increase MSPs roles in helping to build disaster resilience, the author reinforces the need for a greater provision of resources (human, technical and financial) to be directed to the local MSPs, in addition to strengthening relationships between MSPs and other existing stakeholders and networks in DRR.

\subsubsection{Provide more support to local multi-stakeholder platforms}

The importance of building resilience at the local level has been increasingly emphasised in the DRR literature (IFRC, 2004; Djalante et al., 2012; Tanner et al., 2010; Rose et al., 2006; Cutter et al., 2008; Mette, 2012). Capacity and capability of local actors can increase due to improved availability of resources (e.g. Kusumasari and Alam, 2012). Involvement of various stakeholders can lead to and facilitate information and knowledge sharing. Furthermore, availability of resources can also increase local preparedness and response. The GPDRR has continuously been supported by the UNISDR. Through this support, it has been able to carry out its tasks to increase collaboration between stakeholders in DRR, to support regional, national and local DRR platforms, and to create stronger links with other related organisations and networks. The evaluation of DRR platforms in the AsiaPacific region also highlighted the requirement for more support from governments for local platforms to gain legitimacy and recognition (UNISDR-AP, 2010). The progress of Indonesian MSPs is an exception rather than a norm in the region, due to the MSPs gain strong support from the government. This level of support needs to be extended specifically to enhance the participation of communities and groups at the grassroots level and, in particular, the need to support capacity of local governments and local NGOs as well as facilitating for focal point/champions. 


\subsubsection{Create more links with established networks especially those based thematically on the HFA priorities}

These relatively new MSPs should not overlook the existing structures and networks in trying to increase engagement and cooperation among DRR actors. The author found that engagement with other established networks tends to happen more at the international and regional level, and less or even none at the national and local level. Recent reports on HFA implementation, such as the Mid-Term Review (UNISDR, 2011e) and the regional (UNISDR-AP, 2010) and national (BNPB, 2010) progress reports for DRR platforms emphasise the need to increase the role of thematic regional and inter-governmental organisations (IGOs) in enhancing cooperation.

There are several key thematic platforms at the different levels. Globally, there is the International Recovery Platform (IRP, 2011). There are also hazard warning networks, such as the Pacific Tsunami Warning Centre (NOAA, 2011), the International Tsunami Information Centre (ITIC, 2011), drought networks (e.g. DRI, 2011) and earthquake initiatives (e.g. USGS, 2011; EMI, 2011). Despite the existence of these thematic platforms, engagement seems to happen only at the international level especially within the Global Platform. Hence, the regional and national platforms need to initiate better communication with the thematic platform. There is also an increasing recognition of the importance of knowledge provision and education, as demonstrated by the proliferation of knowledge platforms (e.g. PreventionWeb, 2011c), the adaptation platform (e.g. weADAPT, 2011), Indonesia Disaster Database (BNPB, 2011a) and the 3W platform in Indonesia (UNTWG, 2006b). This is a very positive step towards building disaster resilience. However, there is less progress in other parts of the region. The CDE is the only MSP engaged in the education sector in Indonesia. During their second meeting in 2010 in Jakarta, the members agreed that the CDE needs to be positioned strategically within the working mechanisms of DRR, within other global thematic platforms on education, with the UNISDR, with other educational clusters of humanitarian organisations, with the national platform on education and science, and with other NGOs specialising in disaster education (CDE, 2011).

The role of the Red Cross/Red Crescent (RC) movement has been extremely important in DRR. It is the world's largest humanitarian network, and it aims to provide "protection and assistance to people affected by disasters and conflicts" (IFRC, 2011). The movement was founded in 1919, and currently has 100 million members, volunteers and supporters in 186 nations. It also has the necessary human and financial capacities and government support to implement various DRR activities (IFRC, 2011). It is important that the MSPs coordinate with RC activities. The success of the movement in broadening and sustaining its networks should be harnessed by the newly established DRR platforms.
There are also various networks on the city scale that have important roles in building the resilience of cities to climate change. Networks such as the Cities and Climate Change Initiatives (HABITAT, 2011), C40 Cities Climate Leadership Groups (C40Cities, 2011), Cities Alliance (2011) and Cities for Climate Protections (ICLEI, 2011) are all important stakeholders in the planning and implementation of various programmes in DRR (as well as other areas, such as development, poverty reduction, climate change and gender issues).

Despite all these existing networks, what is also important are the mechanisms or ways by which local MSPs are able to tap into these existing wealth of resources and knowledge.

\subsubsection{Broaden and strengthen engagement with "non-traditional" stakeholders}

This paper reiterates the need for stronger engagement with "non-traditional" stakeholders. These stakeholders have not previously been extensively involved in DRR, and can include sectoral organisations, parliamentary members, scientific and academic communities and the private sector. Similar to the previous recommendation, broad and extensive engagement with various stakeholders seem to happen only at the international level especially within the Global Platform. Parliamentarians should also play a stronger role in setting policies and legislation and in the creation of enabling environments for DRR. An excellent example of parliamentarian involvement is the appointment of Senator Legarda from the Philippines, as the first "champion" of the United Nations Regional Champion for DRR and CCA Asia-Pacific Global (UNISDR, 2008). The engagement of parliamentarians is particularly important, because support from the necessary political authority will help in the implementation of DRR across sectors (GPDRR, 2011a). Despite a recent study by the author on DRR in Indonesia showing that parliament plays an important role in the government's development budget allocation for DRR activities (Djalante et al., 2012), there is still no involvement of the member of the national parliament within the organisations structure of the Indonesian National Platform. There is also a lack of involvement of key sectoral organisations. There is only one government agency, BPPT (Research and Technological Development Board), involved in the platform beside BNPB (National Disaster Management Agency) (BNPB, 2011). Another important stakeholder is the private sector, which is the provider and leader in the construction of resilient infrastructure, sustainable development of urban areas, energy safety and the protection of critical resources (GPDRR, 2011a). While private organisation presence in the Global Platform are highly acknowledged, the Indonesian National Platform is just initiating this inclusion and no private entities in the local platforms were identified. 


\section{Conclusions}

The author has highlighted a number of important insights. First, MSPs play an increasingly important role in DRR; in particular, the international MSPs in improving coordination between multiple stakeholders working at different levels, implementing key activities and in their technical and financial capacities. This MSP mechanism is indeed a useful form of adaptive governance. It allows for involvement of multistakeholder actors at different level with different agendas, it creates space for participation and collaboration, it is often formed through reorganisations, and finally, it creates space for learning and sharing. These are the key contributing factors to build disaster resilience. Second, it has been discussed through the paper that despite the notable progress achieved by the MSPs, several challenges remain in terms of technical capacity and the ability to generate funding to support the activities of the national and local MSPs. This, however, should be understood with care that there are limits of the study's generalisability since it has only focused on Indonesia and Asia. Unavailability of published data has made it particularly difficult to determine the specific capacity or resources allocated to the MSPs at the regional level and in Indonesia. Availability of data is an important factor in ensuring accountability of the MSPs and to enable better and more enhanced coordination in the planning and implementation of DRR activities worldwide.

Utilising Warner's proposition (2008a), the MSPs play a key role in delivering more adaptive management and democratic processes rather than for conflict resolution. Accountability and determination of targets/roles (Bäckstrand, 2006) to position MSPs within the existing DRR governance are two issues that need to be clarified in order to ensure these MSPs can achieve positive outcomes. In the long term, MSPs need to be dynamic mechanisms by which DRR momentum is maintained and the call to build community resilience is strengthened through new alliances with local actors and governments, young people, children, civil societies as well as the private sectors. MSPs need to continue their presence in supporting DRR activities under the current HFA, as well as post-HFA efforts after 2015 (UNISDR, 2012e). They also have key roles in overseeing the alignment of the DRR agenda with sustainable development, especially after the "Rio+20 meeting", where reducing risks and building resilience is one of the 12 issues in the agenda (UNCSD, 2012) and vital to meeting of the Millennium Development Goals targets (United Nations, 2011).
Acknowledgements. The author is thankful for the review and comments provided by her doctoral supervisor, Frank Thomalla of Macquarie University and Cameron Holley of The University of New South Wales, Australia, in preparing this manuscript. Regard is also expressed to the four anonymous reviewers for their valuable feedback. The author is a doctoral student from Indonesia supported by the Australian Development Scholarships and CSIRO's Climate Adaptation Flagship.

Edited by: D. Serre

Reviewed by: three anonymous referees

\section{References}

ACDM: ASEAN Committee on Disaster Management: http://www. aseansec.org/18444.htm, last access 1 September 2012.

Argyris, C. and Schoen, D. A.: Theory in Practice: Increasing Professional Effectiveness, Jossey-Bass, San Fransisco, CA, 1974.

AADMER: ASEAN Agreement on Disaster Management and Emergency Response, ASEAN, http://www.aseansec.org/17579. htm, last access 1 September 2012, 2005.

Bäckstrand, K.: Multi-Stakeholder Partnerships for Sustainable Development: Rethinking Legitimacy, Accountability and Effectiveness, European Environment, 16, 290-306, 2006.

Biermann, F., Chan, M.-s., Merct, A., and Pattberg, P.: Multistakeholder Partnership for Sustainable Development: Does the Promise Hold?, in: Partnerships for Sustainable Development. Reflections on Theory and Practice, edited by: Glasbergen, P., Biermann, F., and Mol, A. P. J., Edward Elgar, Cheltenham, 2007.

BNPB: Indonesia National progress report on the implementation of the Hyogo Framework for Action (2009-2011), Badan Nasional Penanggulangan Bencana, Jakarta, 2010.

BNPB: Data dan Informasi Bencana Indonesia: http: //dibi.bnpb.go.id/DesInventar/dashboard.jsp?countrycode= id\&continue=y\&lang=ID, last access: 1 November $2011 \mathrm{a}$.

BNPB: Serah terima kepengurusan Planas PRB: http://bnpb.go.id/ website/asp/berita_list.asp?id=581, last access: 1 May $2011 \mathrm{~b}$.

Bruneau, M., Chang, S. E., Eguchi, R. T., Lee, G. C., O'Rourke, T. D., Reinhorn, A. M., Shinozuka, M., Tierney, K., Wallace, W. A., and Von Winterfeldt, D.: A Framework to Quantitatively Assess and Enhance the Seismic Resilience of Communities, Earthquake Spectra, 19, 733-752, 2003.

Brunner, R., Steelman, T., Coe-Juell, L., Cromley, C., Edwards, C., and Tucker, D.: Adaptive governance: integrating science, policy and decision making, Columbia University Press, New York, 2005.

C40Cities: About Us: http://live.c40cities.org/about-us/, last access: 1 November 2011.

Carlsson, L. and Berkes, F.: Co-management: concepts and methodological implications, J. Environm. Manag., 75, 65-76, 2005.

Carpenter, S., Walker, B., Anderies, J. M., and Abel, N.: From Metaphor to Measurement: Resilience of What to What?, Ecosystems, 4, 765-781, 2001.

CCE: The Community Resilience Manual: A Resource for Rural Recovery \& Renewal, Center for Community Enterprise, Canada, 2000. 
CDE: About CDE in A Framework for School-based disaster preparedness http://www.preventionweb.net/files/26013_ 26008aframeworkofschoolbaseddisaste.pdf, 2011.

Christensen, S. M., Tarp, P., and Hjorts $\varnothing$, C. N.: Mangrove forest management planning in coastal buffer and conservation zones, Vietnam: A multimethodological approach incorporating multiple stakeholders, Ocean Coast. Manag., 51, 712-726, 2008.

Cities Alliance: About Cities Alliance: http://www.citiesalliance. org/ca/about-cities-alliance, last access: 1 November 2011.

Cutter, S. L., Barnes, L., Berry, M., Burton, C., Evans, E., Tate, E., and Webb, J.: A place-based model for understanding community resilience to natural disasters, Global Environ. Change, 18, 598-606, 2008.

Dietz, T., Ostrom, E., and Stern, P. C.: The Struggle to Govern the Commons, Science, 302, 1907-1912, doi:10.1126/science.1091015, 2003.

Djalante, R.: Identifying Drivers, Barriers and Opportunities for Integrating Disaster Risk Reduction and Climate Change Adaptation in Indonesia: An Analysis Based on the Earth System Governance Framework, edited by: Leal Filho, W., Climate Change Management, Springer Berlin Heidelberg, 131147, doi:10.1007/978-3-642-31110-9_9, 2013.

Djalante, R. and Thomalla, F.: Community Resilience to Natural Hazards and Climate Change Impacts: A Review of Definitions and Operational Frameworks, Asian J. Environ. Disaster Manag., 3, 339-355, doi:10.3850/S1793924011000897, 2011.

Djalante, R. and Thomalla, F.: Disaster risk reduction and climate change adaptation in Indonesia: institutional challenges and opportunities for integration, International Journal of Disaster Resilience in the Built Environment, 3, 5-5, 2012.

Djalante, R., Holley, C., and Thomalla, F.: Adaptive Governance and Managing Resilience to Natural Hazards, Int. J. Disaster Risk Sci., 2, 1-14, doi:10.1007/s13753-011-0015-6, 2011.

Djalante, R., Thomalla, F., Sinapoy, M., and Carnegie, M.: Building resilience to natural hazards in Indonesia: progress and challenges in implementing the Hyogo Framework for Action, Nat. Hazards, 1-25, doi:10.1007/s11069-012-0106-8, 2012.

DRI: Drought Research Initiative: http://www.drinetwork.ca/, last access: 1 November 2011.

Elbakidze, M., Angelstam, P. K., Sandstrom, C., and Axelsson, R.: Multi-Stakeholder Collaboration in Russian and Swedish Model Forest Initiatives: Adaptive Governance Toward Sustainable Forest Management?, Ecol. Soc., 15, 14, 2010.

EM-DAT: Annual Disaster Statistical Review: The Numbers and Trends, Centre for Research on the Epidemiology of Disasters (CRED), Universite catolique de Louvain, Brussels, Belgium, http://www.cred.be/sites/default/files/ADSR_2010.pdf, 2010.

EM-DAT: The International Disaster Database: http://www.emdat. be/result-country-profile, last access: 1 October 2011, 2011.

EM-DAT: Top 10 natural disasters in Indonesia http://www.emdat. be/result-country-profile, access: 11 May 2012.

EMI: Earthquake and Megacities Initiative: http://www. emi-megacities.org/home/, access: 1 November 2011.

Farazmand, A.: Learning from the Katrina crisis: A global and international perspective with implications for future crisis management, Public Administration Review, 67, 149-159, 2007.

Faysse, N.: Troubles on the way: An analysis of the challenges faced by multi-stakeholder platforms, Natural Resources Forum, 30, 219-229, doi:10.1111/j.1477-8947.2006.00112.x, 2006.
Folke, C.: Resilience: The emergence of a perspective for socialecological systems analyses, Global Environmental Change, 16, 253-267, 2006.

Folke, C., Hahn, T., Olsson, P., and Norberg, J.: Adaptive Governance of Social-Ecological System, Annual Rev. Environ. Resour., 30, 441-473, 2005.

Freeman, J.: Collaborative Governance in the Administrative State, UCLA Law Review 45, 1-98, 1997.

Fung, A.: Varieties of Participation in Complex Governance, Public Administration Review, 66, 66-75, doi:10.1111/j.15406210.2006.00667.x, 2006.

Germanwatch: Global Climate Risk Index 2010, Germanwatch, Berlin, http://www.germanwatch.org/klima/cri2010.pdf, 2010.

Germanwatch: Global Climate Risk Index 2011, Germanwatch, http://www.germanwatch.org/klima/cri2011.pdf, 2011.

GFDRR: GFDRR Country Programming Framework: Indonesia, Global Fund for Disaster Risk Reduction, http://www.gfdrr.org/gfdrr/sites/gfdrr.org/files/publication/ GFDRR_annual_report_2010.pdf, 2010a.

GFDRR: Partnership Charter, Global Facility for Disaster Reduction and Recovery, Washington DC, http://gfdrr.org/ ctryprogram_pdfs/id.pdf, 2010b.

GFDRR: Annual Report, Global Facility for Disaster Reduction and Recovery, Washington DC, https://www.gfdrr.org/gfdrr/sites/ gfdrr.org/files/publication/GFDRR_Partnership_Charter_2010. pdf 2010c.

GFDRR: About Global Facility for Disaster Reduction and Recovery: http://www.gfdrr.org/gfdrr/node/1, last access: 1 November 2011 .

GFDRR: Service and Business Lines: http://www.gfdrr.org/gfdrr/ node/43, last access: 1 March 2012a.

GFDRR: Governance Structure: http://www.gfdrr.org/gfdrr/sites/ gfdrr.org/files/documents/Governance\%20Structure.pdf, last access: 1 March 2012b.

GFDRR: Global and Regional PArtnership - Track I: http://www. gfdrr.org/gfdrr/node/41, last access: 1 March 2012c.

GFDRR: South-South Cooperation: http://www.gfdrr.org/gfdrr/ RR_SSC, last access: 1 March 2012d.

GFDRR: Dollar Breakdown: http:/www.gfdrr.org/gfdrr/sites/ gfdrr.org/files/GFDRR_Dollar_Breakdown_0.pdf, last access: 1 March 2012e.

GFDRR: Donors: http://www.gfdrr.org/gfdrr/node/56, last access: 1 March 2012f.

GFDRR: About GFDRR: http://www.gfdrr.org/gfdrr/node/1, last access: 1 March 2012g.

GNDR: Who we are: http://www.globalnetwork-dr.org/about-us. html, last access: 1 March 2012a.

GNDR: Main GNDR Institutional Donor Funding: http: //www.globalnetwork-dr.org/donor-support.html, last access: 1 March 2012b.

GNDR: Sasakawa Recognition http://www.globalnetwork-dr.org/ sasakawa-recognition.html, last access: 1 March 2012c.

Goldstein, B. E.: Skunkworks in the embers of the Cedar fire: Enhancing resilience in the aftermath of disaster, Human Ecology, 36, 15-28, doi:10.1007/s10745-007-9133-6, 2008.

GPDRR: Chair's Summary, Global Platform for Disaster Risk Reduction, Geneva, http://www.preventionweb.net/files/20102 gp2011chairssummary.pdf, 2011a. 
GPDRR: Discussion Paper, Global Platform for Disaster Risk Reduction, Geneva, http://www.preventionweb.net/globalplatform/ 2011/documents/documents/DiscussionPaper.pdf, 2011b.

HABITAT, U.: Cities and Climate Change Initiatives: http://www. unhabitat.org/categories.asp? catid $=550$, last access: 1 November 2011.

Hemmati, M.: Multi-stakeholder Processes for Governance and Sustainability: Beyond Deadlock and Conflict, Earthscan Publications Ltd, London, 2002a.

Hemmati, M.: The World Commission on Dams as a MultiStakeholder Process: Some Future Challenges, Politics and the Life Sciences, 21, 63-66, 2002 b.

Holley, C.: Facilitating Monitoring, Subverting Self-Interest and Limiting Discretion: Learning from "New" Forms of Accountability in Practice, Columbia Journal of Environmental Law, 36, 127-211, 2010.

Holley, C., Gunningham, N., and Shearing, C.: The New Environmental Governance, Routledge, London, 2011.

Holling, C. S.: Resilience and Stability of Ecological Systems, Ann. Rev. Ecol. Syst., 4, 1-23, doi:10.1146/annurev.es.04.110173.000245, 1973.

Holling, C. S.: Adaptive environmental assessment and management, Wiley-Interscience., Chichester, xviii + 377 pp., 1978.

ICLEI: Local Governments for Sustainability: http://www.iclei. org/, last access: 1 November 2011.

IDNDR: World Conference on Natural Disaster Reduction, The United Nations, http://www.preventionweb.net/files/10996_ N9437604.pdf, Yokohama, 1994.

IFRC: A Framework for community safety and resilience: in the face of disaster risk, http://www.ifrc.org/Global/Case\% 20studies/Disasters/cs-framework-community-en.pdf, 2008.

IFRC: World Disaster Report 2010, International Federation of Red Cross and Red Crescent Society, http://www.ifrc.org/Global/ Publications/disasters/WDR/WDR2010-full.pdf, 2010.

IFRC: History: http://www.ifrc.org/en/who-we-are/history/, last access: 1 November 2011.

IGRP: Integrated Risk Governance Project, http://www.irg-project. org/, 2010.

Ikeda, S., Sato, T., and Fukuzono, T.: Towards an integrated management framework for emerging disaster risks in Japan, Nat. Hazards, 44, 267-280, doi:10.1007/s11069-007-9124-3, 2008.

IPCC: Fourth Assessment Report in: Climate Change 2007 : Impact, Adaptation and Vulnerability. Contribution of Working Group II to the Fourth Assessment Report of the Intergovernmental Panel on Climate Change, edited by: Parry, M. L., Canziani, O. F., Palutikof, J. P., van der Linden, P. J., and Hanson, C. E., Cambridge University Press, Cambridge, UK and New York, USA, 2007.

IRP: About IRP: http://www.recoveryplatform.org/about_irp/, last access: 1 November 2011.

ITIC: Home: http://itic.ioc-unesco.org/, last access: 1 November 2011.

Jabeen, H., Johnson, C., and Allen, A.: Built-in resilience: learning from grassroots coping strategies for climate variability, Environment and Urbanization, 22, 415-431, doi:10.1177/0956247810379937, 2010.

Josef, L.: Cities and Calamities: Learning from Post-Disaster Response in Indonesia, J. Urban Health, 84, 144-153, 2007.
Klein, R. J. T., Nicholls, R. J., and Thomalla, F.: Resilience to natural hazards: How useful is this concept?, Global Environmental Change Part B: Environmental Hazards, 5, 35-45, 2003.

Leach, W. D., Pelkey, N. W., and Sabatier, P. A.: Stakeholder partnerships as collaborative policymaking: Evaluation criteria applied to watershed management in California and Washington, J. Anal. Manage., 21, 645-670, doi:10.1002/pam.10079, 2002.

Lockwood, M., Davidson, J., Curtis, A., Stratford, E., and Griffith, R.: Governance Principles for Natural Resource Management, Soc. Nat. Resour., 23, 986-1001, doi:10.1080/08941920802178214, 2010.

Manyena, S. B.: The concept of resilience revisited, Disasters, 30, 434-450, 2006.

Maplecroft: Natural Disaster Risk Index 2010, Maplecroft, London, UK, http://www.preventionweb.net/files/ 14169_NaturalDisasters2010.pdf, 2010.

Maplecroft: Climate Change Vulnerability Index 2011, http:// maplecroft.com/about/news/ccvi.html, 2011.

McGinnis, M. D.: Polycentric Governance and Development: Reasings from the Workshop in Political Theory and Policy Analysis, Michigan University Press, Michigan, 1999.

Mette, F. O.: Multi-sited resilience: The mutual construction of "local" and "global" understandings and practices of adaptation and innovation, Appl. Geogr., 33, 112-118, doi:10.1016/j.apgeog.2011.10.007, 2012.

Moellenkamp, S., Lamers, M., Huesmann, C., Rotter, S., PahlWostl, C., Speil, K., and Pohl, W.: Informal Participatory Platforms for Adaptive Management. Insights into Niche-finding, Collaborative Design and Outcomes from a Participatory Process in the Rhine Basin, Ecol. Soc., 15, 4, 41, 2010.

MPBI: Kepengurusuan Platform Nasional Pengurangan Risiko Bencana Terbentuk: http://www.mpbi.org/content/kepengurusuan-platform-nasionalpengurangan-risiko-bencana-terbentuk, last access: 1 May 2011.

NOAA: Pacific Tsunami Warning Center: http://ptwc.weather.gov/, last access: 1 November 2011.

Norris, F., Stevens, S., Pfefferbaum, B., Wyche, K., and Pfefferbaum, R.: Community Resilience as a Metaphor, Theory, Set of Capacities, and Strategy for Disaster Readiness, Am. J. Commun. Psychol., 41, 127-150, doi:10.1007/s10464-007-9156-6, 2008.

Olsson, P., Folke, C., and Berkes, F.: Adaptive comanagement for building resilience in social-ecological systems, Environ. Manag., 34, 75-90, doi:10.1007/s00267-003-0101-7, 2004.

Ostrom, E.: Governing the Commons: The Evolution of Institutions for Collective Action, Cambridge University Press, 298 pp., 1990.

Pahl-Wostl, C.: Requirements for adaptive water management, Adaptive and Integrated Water Management: Coping with Complexity and Uncertainty, 1-22, 2008.

Parker, C. and Braithwaite, J.: Regulation, in: The Oxford Handbook of Legal Studies, edited by: Cane, P. and Tushnet, M., Oxford University Press, Oxford, 119-145, 2003.

Paton, D. and Johnston, D.: Disasters and communities: vulnerability, resilience and preparedness, Disaster Prevention \& Management, 10, 270-277, 2001.

Planas PRB: About (Tentang Kami): http://www.planasprb.net/en, last access: 1 March 2009. 
Plummer, R. and Fennell, D. A.: Managing protected areas for sustainable tourism: prospects for adaptive comanagement, Journal of Sustainable Tourism, 17, 149-168, doi:10.1080/09669580802359301, 2009.

PreventionWeb: Regional Platforms and DRR Strategies: http://www.preventionweb.net/english/hyogo/regional/?pid:

47\&pil:1, last access: 1 November 2011a.

PreventionWeb: Serving the Information Needs of the Disaster Reduction Community: http://www.preventionweb.net/english/ ?logotext, last access: 1 November $2011 \mathrm{~b}$.

PreventionWeb: Regional Platforms and DRR Strategies: http://www.preventionweb.net/english/hyogo/regional/?pid: 47\&pil:1, last access: 1 November 2011c.

PreventionWeb: National Platform List: http://www.preventionweb. net/english/hyogo/national/list/?pid:23\&pih:2, last access: 1 November 2011d.

Renn, O.: Risk Governance: Coping with Uncertainty in a Complex World, Earthscan, London, UK, 2008.

Rose, A.: Economic resilience to natural and man-made disasters: Multidisciplinary origins and contextual dimensions, Environ. Haz., 7, 383-398, doi:10.1016/j.envhaz.2007.10.001, 2007.

Rose, A., Paton, D., and Johnson, D. M.: Disaster Resilience: An Integrated Approach, 2006.

SCDRR: Safer Communities through Disaster Risk Reduction: Laporan Kajian Kebutuhan Daerah dan Rencana Aksi SCDRR di Tujuh Lokasi, Jakarta, http://sc-drr.org/index.php?view= news\&id=59, 2008.

Steins, N. A. and Edwards, V. M.: Platforms for collective action in multiple-use common-pool resources, Agriculture and Human Values, 16, 241-255, doi:10.1023/a:1007591401621, 1999.

Tanner, T., Mitchell, T., Polack, E., and Guenther, B.: Resilience to natural hazards: a geographic perspective, Institute of Development Studies, http://dx.doi.org/10.1007/s11069-009-9407-y, 2010.

The World Bank: Natural Disaster Hotspots: A Global Risk Analysis, The World Bank, 2005.

Tobin, G. A.: Sustainability and community resilience: the holy grail of hazards planning?, Global Environmental Change Part B: Environmental Hazards, 1, 13-25, 1999.

Twigg, J.: Characteristics of a Disaster-resilient Community: A Guidance Note, DFID Disaster Risk Reduction Interagency Coordination Group, https://practicalaction.org/docs/ia1/ community-characteristics-en-lowres.pdf, 2007.

UNCSD: RIO 2012 Issues Briefs No. 8: Disaster Risk Reduction and Resilience Building, United Nations Conference on Sustainable Development, http://www.uncsd2012.org/rio20/content/ documents/225ib8.pdf, 2012.

UNDP Indonesia: Lessons Learned Indonesia's Partnership for Disaster Risk Reduction, The National Platform for DRR and the University Forum, United Nations Development Program Indonesia, Jakarta, http://www.undp.or.id/pubs/docs/Lessons\% 20Learned\%20Indonesias\%20partnership\%20for\%20Disaster\% 20Risk\%20Reduction.pdf, 2008.

UNISDR-AP: 2008-2009 Biennial Report and 2010-2011 Work Plan Highlights, UNISDR Asia and the Pacific, Bangkok, http: //www.unisdr.org/files/13210_ISDRAP0809reportreduced1.pdf, 2010.

UNISDR: Inter-Agency Task Force on Disaster Reduction: Membership 2000-2005: http://www.unisdr.org/2005/task-force/ tf-members-eng.htm, (last access: 11 May 2012), 2000a.

UNISDR: Inter-Agency Task Force on Disaster Reduction: Functions and Responsibilities: http://www.unisdr.org/2005/ task-force/tf-functions-responsibilities-eng.htm, access: May 11, 2012, 2000b.

UNISDR: Inter-Agency Task Force on Disaster Reduction (IATFDR): http://www.unisdr.org/2005/task-force/tf-meeting-1st-eng. htm, last access: 1 November 2000c.

UNISDR: Hyogo Framework for Action 2005-2015: Building the Resilience of Nations and Communities to Disasters, 2005.

UNISDR: Guidelines: national platform for disaster risk reduction, United Nations, Geneva, http://www.unisdr.org/files/601_ engguidelinesnpdrr.pdf, 2007a.

UNISDR: Senator Loren Legarda appointed First "champion" for disaster risk reduction, United Nations International Strategy for Disaster Reduction, Geneva, http://www.unisdr.org/files/16196_ pr200813senatorlorenlegardaappointe.pdf, 2008.

UNISDR: Progress Review of National Platofms for DRR in the Asia and Pacific Region, United Nations International Strategy for Disaster Reduction Secretatiat, Asia and the Pacific, Bankok, http://www.unisdr.org/files/12082 ProgressReviewofNationalPlatformsfo.pdf, 2009b.

UNISDR: Summary Annual Report and Financial Statement, United Nations International Strategy for Disaster Reduction, Geneva, http://www.unisdr.org/files/ 19711_unisdrsummaryannualreportandfinanci.pdf, 2010a.

UNISDR: Indonesia strengthens bid to make schools and hospital safed: http://www.unisdr.org/archive/15103, last access: 1 March 2010b.

UNISDR: Global Assessment Report on Disaster Risk Reduction: Revealing Risk, Redefining Development, United Nations, Geneva, http://www.preventionweb.net/english/hyogo/gar/ 2011/en/bgdocs/GAR-2011/GAR2011_Report_FrontCover.pdf, 2011a.

UNISDR: The Global Platform for Disaster Risk Reduction: http://www.unisdr.org/we/coordinate/globalplatform, last access: 1 November 2011 b.

UNISDR: Third Session of the Global Platform for Disaster Risk Reduction and World Reconstruction Conference: Chair's Summary: United Nations, Geneva, http://www.preventionweb.net/ files/20102_gp2011chairssummary.pdf, 2011c.

UNISDR: Hyogo Framework for Action 2005-2015 Mid-Term Review, United Nations, Geneva, http://unisdr.org/we/inform/ publications/18197, 2011d.

UNISDR: Mid-Term Review 2010-2011 of the Hyogo Framework for Action 2005-2015 - Building the Resilience on Nations and Communities to Disasters, Geneva, http://www.preventionweb. net/files/18197_midterm.pdf, 2011e.

UNISDR: Implementing the Hyogo Framework for Action in Europe: Advances and Challenges, UNISDR, http://www. preventionweb.net/files/19690_hfareportwebfinal.pdf, $2011 \mathrm{f}$.

UNISDR: In-depth study on the United Nations contribution to the implementation of the Hyogo Framework for Action, United Nations, Geneva, http://www.unisdr.org/files/18197_ 206vonoelreich.indepthstudyoftheunc.pdf, 2011g.

UNISDR: Global Platform for Disaster Risk Reduction. Third Session, 8-13 May 2011, Opening ceremony, 2011h.

UNISDR: About the Global Platfrom for Disaster Risk Reduction: http://www.preventionweb.net/globalplatform/2011/about/, 
last access: 1 November $2011 \mathrm{i}$.

UNISDR: UNISDR in the UN System: http://unisdr.org/ who-we-are/unisdr-in-un, last access: 30 May $2011 \mathrm{j}$.

UNISDR: Thematic Platforms: http://www.unisdr.org/partners/ thematic-platforms, last access: 30 May 2012a.

UNISDR: What we do: http://www.unisdr.org/we, last access: 1 March 2012b.

UNISDR: Our Mandate: http://www.unisdr.org/who-we-are/ mandate, last access: 1 March 2012c.

UNISDR: Countries and National Platforms: http://www.unisdr. org/partners/countries, last access: 1 March 2012d.

UNISDR: Towards a Post-2015 Framework for Disaster Risk Reduction, United Nations International Strategy for Disaster Reduction, Geneva, http://www.unisdr.org/files/25129 towardsapost2015frameworkfordisaste.pdf, 2012e.

UNISDR: Donor Partnerships: http://www.unisdr.org/who-we-are/ donors, last access: 1 March 2012f.

United Nations: The Millenium Development Goals Report, United Nations, New York, http://www.un.org/millenniumgoals/pdf/ \%282011_E\%29\%20MDG\%20Report\%202011_Book\%20LR. pdf, 2011.

UNTWG: The United Nationas Technical Working Group for Disaser Risk Reduction, http://ochaonline.un.org/AboutUs/ DisasterRiskReduction/tabid/3733/language/en-US/Default. aspx, 2006a.

UNTWG: Who Does What Where: http://ochaonline.un.org/ indonesia/WhoWhatWhere/tabid/3308/language/en-US/Default. aspx, 2006b.
UNU-EHS: WorldRiskReport 2011, The United Nations University's Institute for Environment and Human Security, Bonn, http: //www.ehs.unu.edu/file/get/9018, 2011.

US/IOTWS: How Resilient is Your Coastal Community? A Guide for Evaluating Coastal Community Resilience to Tsunamis and Other Hazards, U.S. Indian Ocean Tsunami Warning System Program, Bangkok, Thailand, http://www.ioc-tsunami.org, 2007.

USGS: Earthquake Hazards Program: http://earthquake.usgs.gov/, last access: 1 November 2011.

Van der Torn, P. and Pasman, H. J.: How to plan for emergency and disaster response operations in view of structural risk reduction, Resilience of Cities to Terrorist and Other Threats, 343379, 2008.

Voss, M. and Wagner, K.: Learning from (small) disasters, Nat. Hazards, 55, 657-669, doi:10.1007/s11069-010-9498-5, 2010.

Warner, J. F.: Multi-stakeholder platforms: integrating society in water resource management?, Ambiente \& sociedade, 8, 4-28, 2005.

Warner, J. F.: More Sustainable Participation? Multi-Stakeholder Platforms for Integrated Catchment Management, International J. Water Resour. Development, 22, 15-35, doi:10.1080/07900620500404992, 2006.

Wildavsky, A.: Searching for Safety, Transaction Publisher, New Brunswick, NJ, http://books.google.com.au/books/about/ Searching_for_Safety.html?id=099g 1rhws_kC\&redir_esc=y, 1988.

World Bank: Stakeholder Engagement: A Good Practice Handbook for Companies Doing Business in Emerging Markets, International Finance Corporation: The World Bank Group, Washington, 2007. 